\title{
The Role of Magnesium in Superalloys-A Review
}

\author{
Kumkum Banerjee \\ Research and Development Division, Tata Steel Limited, Jamshedpur, India. \\ Email: kumkum.banerjee@tatasteel.com \\ Received February $17^{\text {th }}, 2011$; revised May $20^{\text {th }}, 2011$; accepted June $17^{\text {th }}, 2011$.
}

\begin{abstract}
The role of magnesium $(\mathrm{Mg})$ in improving the high temperature mechanical properties of the superalloys, like creep, fatigue, tensile ductility, impact toughness etc. have been vividly studied by several authors. On the other hand, very few authors have contradicted the view of any beneficial effect of $\mathrm{Mg}$ on the mechanical properties. This review presents a summary of the open literature related to the effect of $\mathrm{Mg}$ on the microstructure and mechanical properties of superalloys and from which further metallurgical research on the unexamined topics are proposed.
\end{abstract}

Keywords: Superalloy, Magnesium

\section{Introduction}

Over more than three decades several studies have been made on the influence of micro alloying of wrought and cast superalloys with magnesium. It was well recognized that a small addition of minor elements such as $\mathrm{B}, \mathrm{Mg}$, $\mathrm{Ca}$ and rare earths etc. could improve the stress rupture and creep properties significantly [1]. The results with $\mathrm{Mg}$ addition indicate that an optimum addition of magnesium causes enhancement in high temperature mechanical properties. e.g. creep life, creep rupture ductile $=$ ity, high temperature tensile ductility, cyclic stress rupture properties creep-fatigue interaction, crack propagation and hot workability [2-4]. Mg has been shown to improve the creep properties and particularly the high temperature ductility of the wrought alloys due to refinement of the grain boundary carbides and equilibrium segregation [5]. Magnesium addition can also prolong secondary creep stage and develop tertiary creep stage and simultaneously alloys possess longer stress rupture life than the alloys without $\mathrm{Mg}[6]$. The detrimental effect of sulfur has been found to be reduced by the addition of $\mathrm{Mg}$. The results on cast IN-718 superalloy showed that a small amounts of $\mathrm{Mg}$ improved impact toughness and decreased $\mathrm{Nb}$ segregation by decreasing secondary arm spacing, which resulted in less and smaller interdendritic Laves and MC eutectics [5]. Moreover, magnesium also decreased the quantity of $\gamma^{\prime}$ eutectic by segregating to the phase boundaries and thus refining the $\gamma^{\prime}$ eutectic. Small amounts of Mg produced a more spherical as well as more dispersive MC phase. In contrast to this, detrimental effects of $\mathrm{Mg}$ on creep life and ductility has been reported in some studies $[7,8]$. In the attempt to achieve favourable properties many investtigations have been made to assess the optimum $\mathrm{Mg}$ concentration in the alloys and its relationship to microstructure and properties [1,9-16]. However, common conclusions have not yet been achieved on this problem. This might be due to the different procedures used to determine the $\mathrm{Mg}$ percent and lack of comparability of the influence of magnesium in small-scale laboratory test and industrial ingot.

Thus, the unique effect of $\mathrm{Mg}$ has been established for many superalloys and the beneficial influence of $\mathrm{Mg}$ has been attributed to the refinement of carbides, $\delta$-phase and Laves phase on grain boundary and reducing the detrimental effect of sulfur. In this paper, the existing findings in this area are critically reviewed and the unexamined areas are pointed out for carrying out further research in this direction.

\section{Influence of Mg on Mechanical Properties and Weldability of Superalloys}

\subsection{Mechanical Properties}

The high temperature symmetrical low cycle fatigue (LCF) $(\mathrm{R}=-1)$ and unsymmetrical LCF $(\mathrm{R}=0.42)$ were studied by Xie et al. [15] on IN- 718 iron and nickel-base superalloys and it was reported that the micro alloying of $\mathrm{Mg}$ (30-50 ppm) showed beneficial effect on unsymmetrical LCF, where crack growth rate decreased by a factor of $3-7$. However, symmetrical tension-compression stress 
controlled high temperature LCF properties remained unaffected.

In the research by Ma et al. $[4,17]$ it was observed that an optimal addition of $\mathrm{Mg}$ to the wrought superalloys (GH33, GH220) prolonged the secondary and especially the tertiary creep $\left(700^{\circ} \mathrm{C} / 392 \mathrm{MPa}\right)$ at low strain rate of steady state creep stage $\left(\varepsilon<10^{-5} \mathrm{~mm} \cdot \mathrm{mm}^{-1} \cdot \mathrm{h}^{-1}\right)$. However, at greater strain rate the effect of $\mathrm{Mg}$ vanished. In a different study, Zhong et al. [2] explained about the similar observation on the effect of $\mathrm{Mg}$ on creep behavior $\left(700^{\circ} \mathrm{C} / 343 \mathrm{MPa}\right)$ of a Ni-base superalloy (GH33). In this case also an optimum $\mathrm{Mg}$ addition prolonged the time for creep crack nucleation and growth rate and which in turn increased the rupture life. In support to this, G. Chen and H. Ge [18] have showed the improvement of creep life and elongation of GH 698 (Figure 1) due to prolongation of secondary creep stage and the development of tertiary creep stage. However, no evidence of influence of creep rate on the alloy was observed. Likewise, several studies have been made by other researchers $[1,19,20]$ and they have also mentioned the beneficial effect of $\mathrm{Mg}$ on creep properties, which has been manifested by the increase in secondary and development of tertiary creep stages and thus improving the rupture life and the elongation. The improved influence of $\mathrm{Mg}$ on creep is attributed to the improved grain boundary ductility arising from the influence of $\mathrm{Mg}$ on the formation and growth of creep cavities. The stress rupture life and ductility observed to be increasing with the increase in $\mathrm{Mg}$ content up to an optimum level followed by a decrease in the properties with further addition of $\mathrm{Mg}$ [18]. It is noteworthy that the optimum $\mathrm{Mg}$ level is different for different alloys. The creep properties, rupture life and stress component of creep of the superalloys containing $\mathrm{Mg}$ were examined by Danien Ke [21] and reported to have significantly improved ductility and rupture life by the impediment of grain boundary sliding and the prevention of nucleation

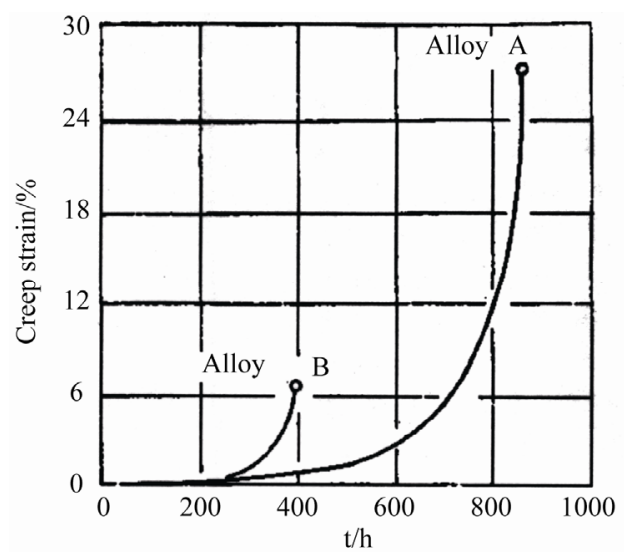

Figure 1. Creep curves of alloy A (containing $0.005 \% \mathrm{Mg}$ ) and $\mathrm{B}(\mathrm{no} \mathrm{Mg})$ at $750^{\circ} \mathrm{C}$ and $343 \mathrm{MPa}$ [18]. and propagation of creep crack growth. The magnesium (0.0094\%) addition to GH 169 improved stress rupture life and stress rupture ductility at temperature $650^{\circ} \mathrm{C}$ (Figure 2) [1]. The alloy with $0.0094 \% \mathrm{Mg}$ gradually softened during long time exposure at $650^{\circ} \mathrm{C}$, therefore stress rupture life decreased and ductility increased mildly. However, the properties were still better than the alloy containing negligible amount of $\mathrm{Mg}(0.0001 \% \mathrm{Mg})$. Bor et al. [22-24] extensively worked on the effect of Mg on creep characteristics, fracture mechanism and carbide characteristics of MAR-M247, a Ni-base superalloy under $1255 \mathrm{~K} / 200 \mathrm{MPa}$ and $1033 \mathrm{~K} / 724 \mathrm{MPa}$ conditions. They observed that under the former testing condition $0.005 \% \mathrm{Mg}$ refined and spheroidized $\mathrm{MC}$ carbide at $\mathrm{GB}$, which enhanced the creep properties, whereas $0.008 \%$ $\mathrm{Mg}$ addition increased the number of $\mathrm{MC}$ at $\mathrm{GB}$, which significantly decreased rupture life and elongation. However, under the condition of $1033 \mathrm{~K} / 724 \mathrm{MPa}$, it was observed that the rupture life and elongation both significantly improved to $3-5$ times with $80 \mathrm{ppm} \mathrm{Mg}$. In this work the transition of fracture initiation site from carbide matrix to a more ductile interface, $\gamma / \gamma^{\prime}$ has been reported [24]. A decrease in the steady state creep rate in the $\mathrm{Mg}$ containing alloys is reported in the literature. Conversely, Chen et al. [25] have emphasized about the insignificant influence of $\mathrm{Mg}$ addition on steady state creep rate, but mentioned that by $\mathrm{Mg}$ addition creep life and elongation $\left(750^{\circ} \mathrm{C} / 1343 \mathrm{MPa}\right)$ were improved. The segregation of $\mathrm{Mg}$ on the cavity surface was reported to be instrumental in lowering the creep cavity growth rate.

Chen et al. [26] in their work on three wrought superalloys including IN-718, studied the effect of $\mathrm{Mg}$ on creep properties $\left(650^{\circ} \mathrm{C}-750^{\circ} \mathrm{C}\right.$ at different stresses), $\operatorname{LCF}\left(700^{\circ} \mathrm{C}\right)$, cyclic stress rupture $\left(650^{\circ} \mathrm{C}\right)$ and fatiguecreep interaction properties $\left(1 \mathrm{HZ}, 650^{\circ} \mathrm{C}\right.$, in air). They

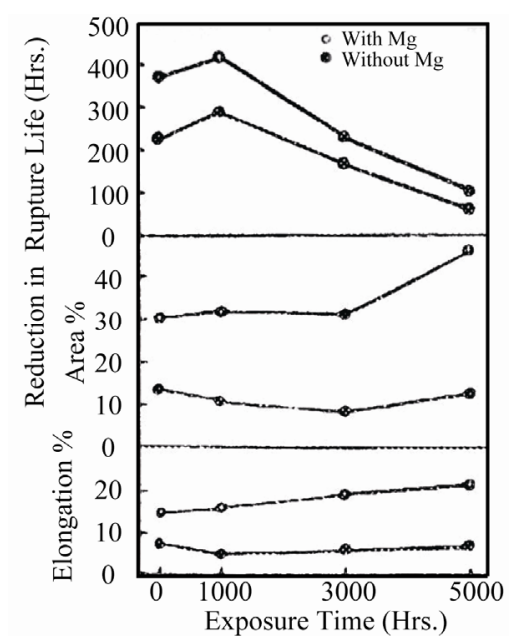

Figure 2. Effect of long time exposures at $650^{\circ} \mathrm{C}$ on $650^{\circ} \mathrm{C}$ /686 MPa stress rupture [1]. 
reported that $\mathrm{Mg}$ did not affect the steady state creep rate. The LCF properties and crack growth rate of LCF at $700^{\circ} \mathrm{C}$ were also unaffected by micro addition of $\mathrm{Mg}$. Conversely, creep rupture life and fatigue failure life were increased in the alloy containing magnesium by reducing the cavity growth rate of the crept samples and increasing the number of cycles for fatigued specimens respectively. Xie et al. [27] in their investigation described that $\mathrm{Mg}$ helped increase the stress rupture life of both the smooth and notched specimen (Figure 3), cyclic stress rupture and also LCF (Figure 4), cyclic stress rupture and also LCF at any grain size. It implies therefore, that the views on the effect of $\mathrm{Mg}$ on LCF are at variance.

There are various literatures explaining the enhancement of stress rupture ductility [28-30] improvement by small addition of $\mathrm{Mg}(1-350 \mathrm{ppm})$. In the early $70 \mathrm{~s}$ Couts et al. [28] studied the effect of $\mathrm{Mg}$ (1 - $350 \mathrm{ppm})$ on the mechanical properties of alloy IN-718 and showed stress rupture ductility improvement in the range of

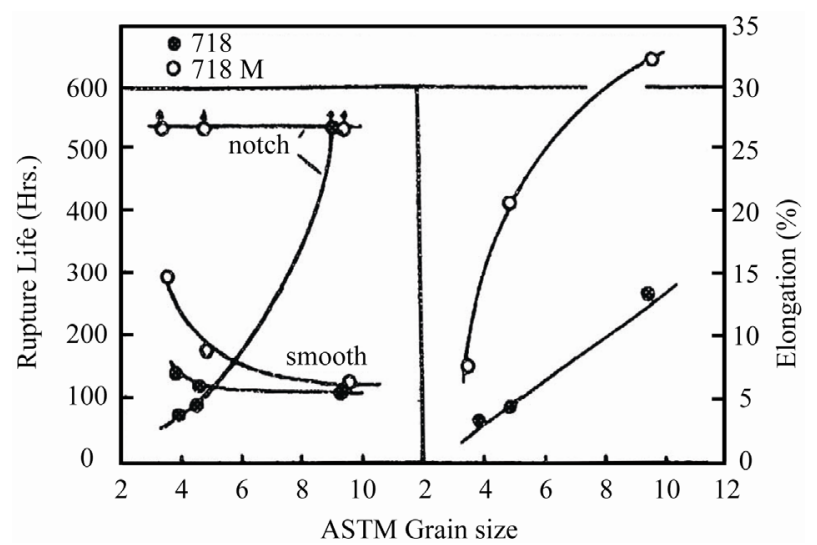

Figure 3. Grain size and $\mathrm{Mg}$ effect on stress rupture life and elongation at $650^{\circ} \mathrm{C}$ and $686 \mathrm{MPa}$ [27].

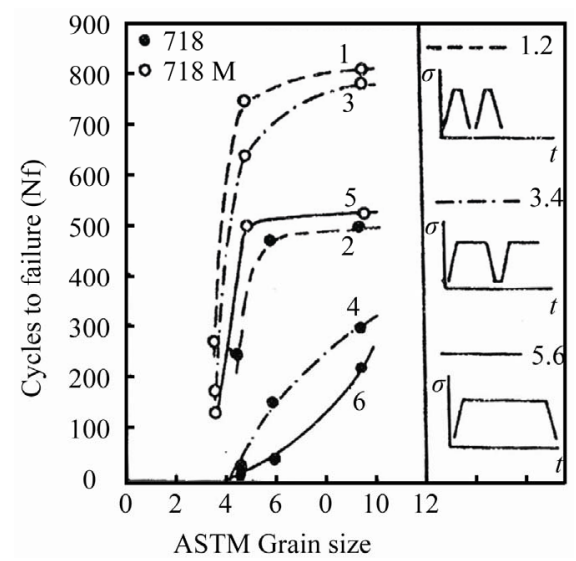

Figure 4. Grain size and Mg effect on cyclic stress rupture life with different holding times at maximum stress of 686 Mpa at $650^{\circ} \mathrm{C}(1,2-5 \mathrm{sec}, 3,4-180 \mathrm{sec}, 5,6-1800 \mathrm{sec})$ [27].
30 - 200 ppm but little was presented in the lower range (up to $100 \mathrm{ppm}$ ) of $\mathrm{Mg}$. In 1971 Muzyka et al. [29] showed beneficial stress rupture ductility improvement at 30 ppm Mg. In 1984, Moyer [30] in his study with extra low-carbon alloy showed a remarkable stress rupture ductility and life improvement with a small addition of $\mathrm{Mg}$ (13 - $19 \mathrm{ppm})$. The beneficial effect of $\mathrm{Mg}$ in alloy IN-718 was observed to be maintained even after long time exposure at $650^{\circ} \mathrm{C}$ [27]. Liu et al. reported [7] $\mathrm{Mg}$ had no beneficial effect on the stress rupture properties as well. This was accounted for the small $\mathrm{Mg}(\mathrm{O}, \mathrm{S})$ particles, which increased void nucleation sites demonstrating negative influence on the mechanical properties. Additionally due to low percent of sulfur, $\mathrm{Mg}$ formed $\mathrm{Ni}_{2} \mathrm{Mg}$ Laves phase, which was harmful to the properties of the alloys. They have also suggested that if the sulfur content can be controlled to a low level, there is no necessity to add $\mathrm{Mg}$ from the industrial point of view.

The stress rupture (smooth and notched), creep-fatigue interaction, notched cyclic stress rupture-all these properties were reported to be improved with the addition of micro alloying of $\mathrm{Mg}(30-70 \mathrm{ppm})$ by the researchers [3, 31]. Crack propagation rate was found to be decreased as well. The stress rupture life of notched $70 \mathrm{ppm} \mathrm{Mg}$ alloy increased from $80 \mathrm{~h}$ to $350 \mathrm{~h}$ whereas rupture life for smooth specimen increased from $70 \mathrm{~h}$ to $100 \mathrm{~h}$ only. In creep-fatigue interaction cycle, life to failure of higher $\mathrm{Mg}$ (70 ppm) alloy was apparently longer than lower $\mathrm{Mg}$ containing alloy. Similarly notched stress rupture life of higher $\mathrm{Mg}$ (70 ppm) alloy was 2158 cycles whereas, it was 653 cycles for lower $\mathrm{Mg}$ containing alloy. These beneficial effects were attributed to the improvement in distribution, morphology and quantity of $\delta$-phase $\left(\mathrm{Ni}_{3} \mathrm{Nb}\right)$ at the grain boundary due to the addition of $\mathrm{Mg}$.

The effect of grain size and $\mathrm{Mg}$ addition on stress rupture and notched cyclic stress rupture were studied [32] and it was concluded that a minute amount (59 ppm) of $\mathrm{Mg}$ and grain refinement might improve high temperature stress rupture notch sensitivity and decrease failure lives of Ni-Fe base superalloy IN-718 even in the presence of duplex grain structure.

A small percent of $\mathrm{Mg}$ also prolonged the secondary creep and tertiary stages of creep resulting in increased stress rupture life and ductility by $\sim 1.5-2.5$ times [1]. The optimum content of $\mathrm{Mg}$ moved down to lower level by the high temperature long time exposure. There was not a significant effect observed by the addition of $\mathrm{Mg}$ on the steady state creep rate. Likewise, Magnesium was reported to have no beneficial effect on the stress rupture properties of Inconel 718 at $650^{\circ} \mathrm{C}, 686 \mathrm{MPa}$ while the sulfur content is not more than $10 \mathrm{ppm}$ [33].

The effect of $\mathrm{Mg}$ on cast superalloys has been investigated in the late $80 \mathrm{~s}$ by Chen et al. [5] and favourable 
effect of $\mathrm{Mg}$ on impact toughness was reported which is shown in Figure 5, which is possibly due to the decrease in interdendritic Laves eutectic (Figure 6) and the refinement of interdendritic segregation of $\mathrm{Nb}$ and $\mathrm{Ti}$, which allowed shorter homogenization cycle. In Figure 7 it is indicated that as the $\mathrm{Mg}$ content increases the Laves phase decreases, the amount of $\delta$ plates around the Laves islands increases. This occurs because the amount of $\mathrm{Nb}$ necessary for Laves phase formation is too small but the $\mathrm{Nb}$ content as high enough for $\delta$-phase formation. The $\delta$ - plates can be eliminated by homogenization much easier than the Laves islands. A large number of fractured MC and Laves particles were observed in the alloy without $\mathrm{Mg}$, whereas a negligible amount of the same was noticed in the alloy containing Mg (Figure 8).

ln another study of Ford [8] it was declared that $\mathrm{Mg}$ had a dual influence on the material property. He pointed out that although $\mathrm{Mg}$ reduced micro porosity in superalloys and increased castability but on the other hand, it decreased high temperature creep life and ductility. The

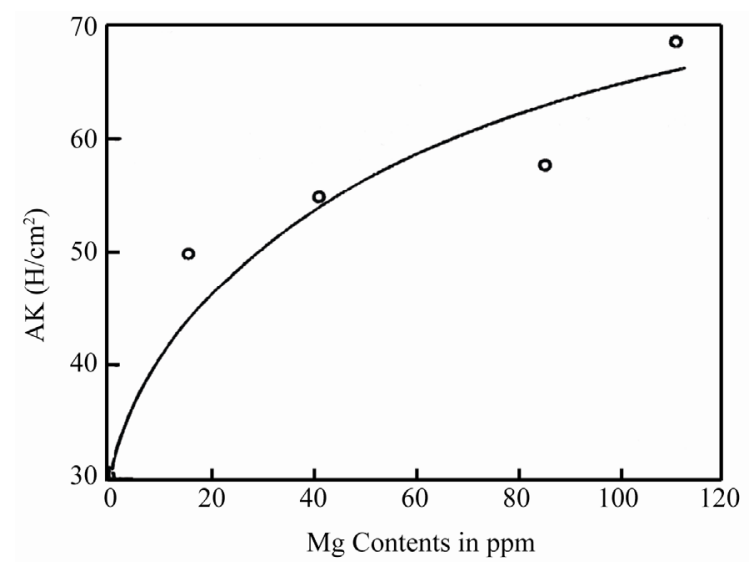

Figure 5. Effect of $\mathrm{Mg}$ addition on impact toughness in cast alloy IN-718 [5].

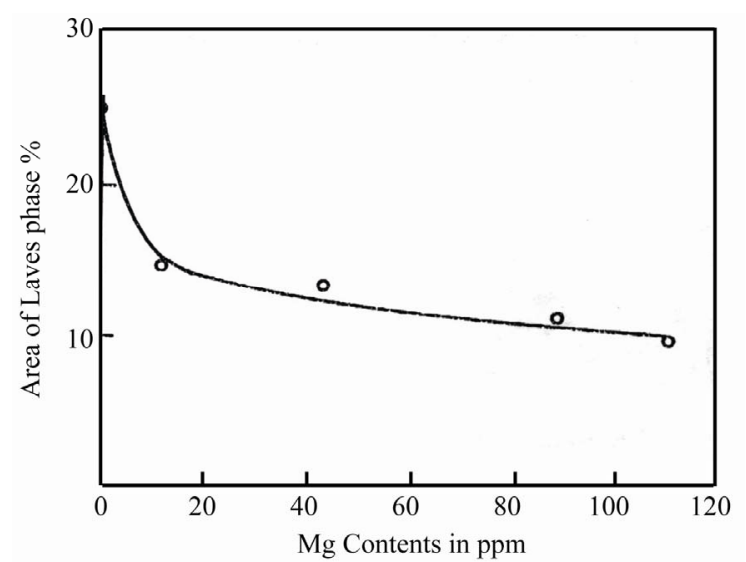

Figure 6. Effect of $\mathrm{Mg}$ contents on the quantity of laves eutectic in cast alloy IN-718 [5]. reason for this effect was not explained although. Bor et al. [22-24] observed that in MAR-M247 nickel based alloy, $0.008 \% \mathrm{Mg}$ increased the number of $\mathrm{MC}$ on grain boundary, which significantly decreased creep rupture life and elongation of the alloy.

Further, Liu et al. [7] reported about the detrimental or no effect of $\mathrm{Mg}$ (76 ppm - $94 \mathrm{ppm}$ ) in their recent studies (in 2001) on IN-718 containing low amount of sulfur content $(<10 \mathrm{ppm})$. Tensile properties did not respond to the addition of $\mathrm{Mg}$ content while the tests were conducted at room temperature, $500^{\circ} \mathrm{C}$ and $650^{\circ} \mathrm{C}$ and the $\mathrm{Mg}$ had no beneficial effect on the stress rupture properties as well.

\subsection{Weldability}

The influence of $\mathrm{Mg}$ on IN-718 weld micro fissuring was investigated by Morrison et al. [34]. The evaluation disclosed that magnesium had some positive influence on the weldability of the alloy. The tests carried out by them in the year 1966 showed no micro fissuring in their lon-

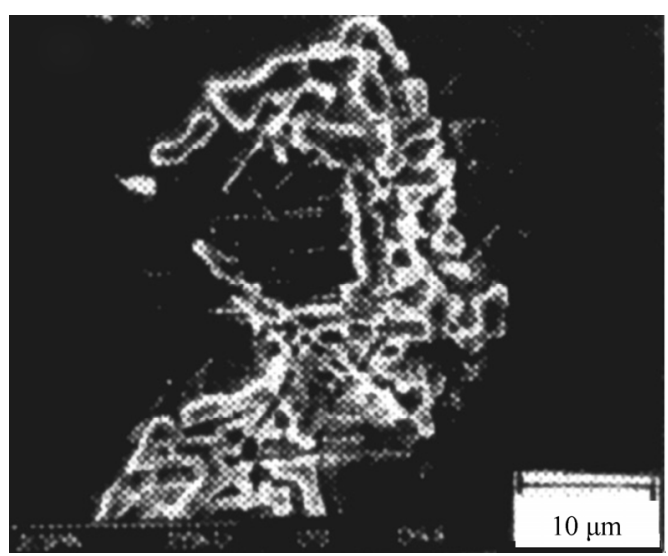

(a)

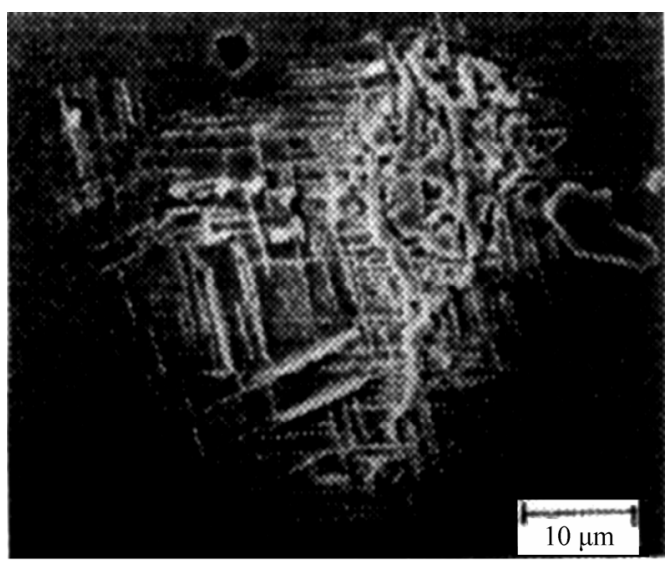

(b)

Figure 7. Effects of $\mathrm{mg}$ and $\delta$ plates around the Laves islands in cast alloy IN-718 (a) alloy without Mg and (b) alloy with $\mathrm{Mg}$ [5]. 


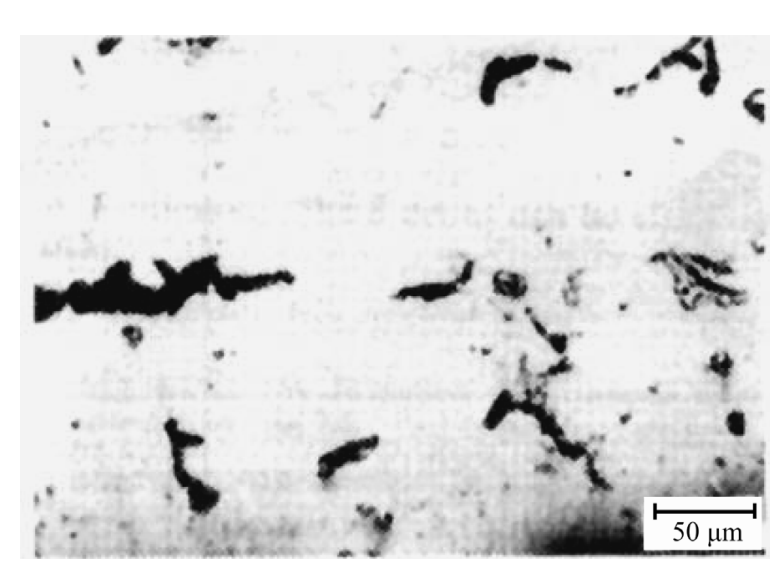

(a)

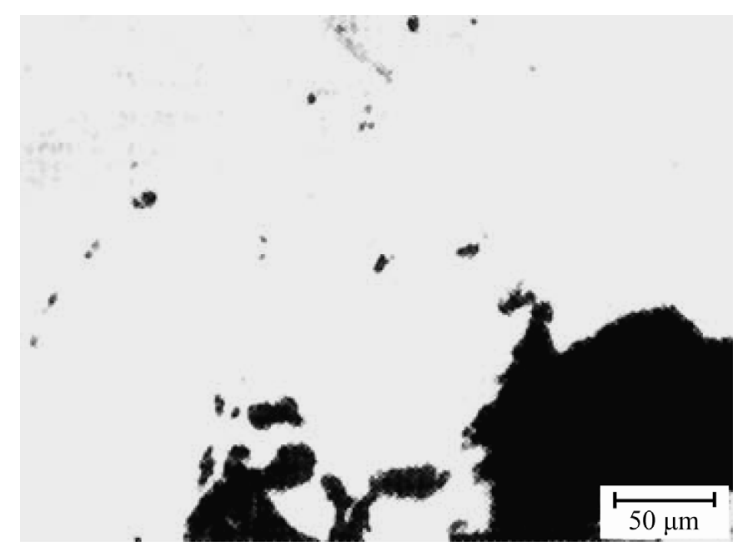

(b)

Figure 8. Micro cracks in impact samples (cast IN-718) (a) alloy without Mg and (b) alloy with Mg [5].

gitudinal and transverse sections of the alloy by the addition of $\mathrm{Mg}$. The tests carried out in 1967 on the prewelded specimens $\left(1150{ }^{\circ} \mathrm{C} / 1 \mathrm{hr}\right.$./AC), welded by TIG showed no cracking with $37 \mathrm{ppm}$ of $\mathrm{Mg}$. However, when the tests were conducted at the same preweld heat treated condition with $52 \mathrm{ppm} \mathrm{Mg}$, micro fissuring was observed. Whereas the preweld temperature of $1060^{\circ} \mathrm{C}$ was compatible with both the $\mathrm{Mg}$ contents. Their result indicated that around $20 \mathrm{ppm}$ of $\mathrm{Mg}$ weldability improvelnent started and at around $30 \mathrm{ppm} \mathrm{Mg}$ and a plateau value was observed.

Liu et al. [7] reported about the detrimental or no effect of Mg (76 ppm-94 ppm) in their recent studies (in 2001) on IN-718 containing low amount of sulfur content $(<10 \mathrm{ppm})$. Tensile properties did not respond to the addition of $\mathrm{Mg}$ content while the tests were conducted at room temperature, $500^{\circ} \mathrm{C}$ and $650^{\circ} \mathrm{C}$. High temperature tensile ductility of wrought heat resistant alloy EP 199, showed a consistency in ductility in the work of Topilin and Tsvetkeva [35]. A fairly high strength and ductility characteristics at $20^{\circ} \mathrm{C}$ and $900^{\circ} \mathrm{C}$ were obtained with $\mathrm{Mg}$ concentration of $150-290 \mathrm{ppm}$. They declared that there was a critical amount of $\mathrm{Mg}(0.005 \%)$ below which the ductility of the alloy decreased sharply. An improved high temperature tensile ductility in a $\mathrm{Mg}$ containing Ni-base alloy was also reported by $\mathrm{Xu}$ et al. [31], but a little effect was realized on tensile strength. The tensile properties at high temperature of $650^{\circ} \mathrm{C}$ were reported to be improved with 30-70 ppm alloying of $\mathrm{Mg}$ [3,31]. A significant increase in reduction in area $(45 \%)$ and elongation $(27 \%)$ was reported. Further, the beneficial effect of higher yield and ultimate tensile strength observed at ambient temperature, due to a small amount of $\mathrm{Mg}$ addition, was observed to be disappeared at higher temperature [1]. Further, Xie et al. reported that Magnesium had almost no influence on tensile strength and ductility in Inconel 718 alloys with low content of sulfur at room temperature, $500^{\circ} \mathrm{C}$ and $650^{\circ} \mathrm{C}[33]$.

\subsection{Hot Ductility Behavior of Superalloys}

Liu and his group [36] performed a series of hot tensile tests to study the effect of $\mathrm{S}$ and $\mathrm{Mg}$ on hot ductility of IN-690 alloy and reported about the beneficial effect of an appropriate addition of $\mathrm{Mg}$. It was observed that with the increase in $\mathrm{S}$ content $(0-80 \mathrm{ppm})$ there was sharp decrease in ductility at high temperatures $900^{\circ} \mathrm{C}-1150^{\circ} \mathrm{C}$ in the absence of $\mathrm{Mg}$. However, a very low level of sulfur content $(<10 \mathrm{ppm})$ showed excellent ductility in the temperature range $900^{\circ} \mathrm{C}-1200^{\circ} \mathrm{C}$. But when the sulfur content exceeded $20 \mathrm{ppm}$, the value of reduction in area was less than $50 \%$ at $900^{\circ} \mathrm{C}-1000^{\circ} \mathrm{C}$, which corresponded to poor hot ductility. It was indicated that sulfur had less influence on ductility at relatively higher temperatures $\left(>1050^{\circ} \mathrm{C}\right)$, which was accounted for softening of the alloy matrix and the possibility of increase in sulfur solubility at higher temperature. When sulfur was about $40 \mathrm{ppm}$, the ductility was reported to be better with $160 \mathrm{ppm}$ of $\mathrm{Mg}$. But at the same sulfur level higher $\mathrm{Mg}$ content had detrimental effect on the ductility. In the late 70's Yamaguchi et al. [37] studied the effect of minor elements $(\mathrm{S}, \mathrm{Ca}, \mathrm{Mg}, \mathrm{Y}$ and $\mathrm{Zr}$ ) on hot workability of solid solution strengthened Ni-base superalloys. The hot workability of Ni-base superalloys is mainly controlled by $\mathrm{dS}=\% \mathrm{~S}-0.8 \mathrm{X} \% \mathrm{Ca}-0.3 \mathrm{X} \mathrm{Mg} \%-0.5 \mathrm{X} \% \mathrm{Y}-$ $0.1 \mathrm{X} \% \mathrm{Zr}$. The dS corresponds to the residual amount of sulfur that is not fixed by strong sulfide forming elements- $\mathrm{Ca}, \mathrm{Mg}, \mathrm{Y}$ and $\mathrm{Zr}$. An excellent hot ductility can be achieved with $0.003>\mathrm{dS}>0.004$. The ductility decreased gradually with $\mathrm{dS}<0.004$ and became extremely poor when $\mathrm{dS}>0.003$. Both $\mathrm{dS}>0$ and $\mathrm{dS}<0$ lowered hot ductility. Hence in order to achieve superior ductility dS should be nearly zero.

In order to strengthen the grain boundaries and change the type of fracture from intergranular to transgranular 
with a corresponding increase in ductility alloying boron, zirconia, magnesium and hafnium is recommended [38, 39] Boron atoms, which are not chemically bonded, together with the atoms of zircon, hafnium and magnesium segregate to grain boundaries and contribute significantly to improving the high temperature properties of superalloys at elevated temperatures [40].

From the aforementioned reported results it is implied that a small amount of $\mathrm{Mg}$ can significantly improve high temperature mechanical properties of some $\mathrm{Ni}$ and Fe-base superalloys. However, to maintain the optimum $\mathrm{Mg}$ concentration in various alloys, different techniques, e.g., VIM, VAR, ESR, VADER (Vacuum Arc Double Electrode Remelting) are being used and have been discussed in the literature [41-43]. Yeniscavich and Fox [44] served a detrimental effect of $\mathrm{Mg}$ and $\mathrm{Si}$ on zero ductility while working on Hastelloy X.

\section{Influence of Mg on Microstructure and Mechanisms Involved}

Magnesium has a great influence on the size, morphology, distribution and quantity of carbide and phases at grain boundaries. The studies indicated that $\mathrm{Mg}$ is a surface-active element and segregation of $\mathrm{Mg}$ takes place at the grain boundaries and the interphases like $\gamma /$ carbide and $\gamma / \gamma^{\prime}[45,46]$. The segregation of $\mathrm{Mg}$ at the interfaces and interphases in turn accounted for the surface-active characteristic of $\mathrm{Mg}$ and hence its high propensity for segregation to interfaces and interphases [22]. $\mathrm{Mg}$ formed an enriched layer of $\mathrm{Mg}$ surrounding the carbide and might influence the transport of carbon and carbide forming elements. This resulted in an isotropic growth of carbides during solidification and eventually led to the refinement and spheroidization of MC carbides both at the grain boundary and within the grain interior $[4$, 22-24]. The spheroidization resulted from $\mathrm{Mg}$ addition improves the stress distribution state at grain boundary thus decreases the possibility of wedge crack at the grain boundary [17].

Hence the coalescence of grain boundary micro voids generated by carbides became the prominent mechanism of creep crack initiation and the crack initiation and propagation in the tertiary stages of creep were retarded and thus the rupture life was subsequently prolonged. The spheroidization of grain boundary carbides resulting from the micro alloying of $\mathrm{Mg}$ resisted the propagation of cracks and the carbides at the tip of the crack may become the nucleating centre for further growth of cracks. However, the stress concentration around the spheroidized carbides is smaller than that of the plate-like carbides and hence the possibility of crack nucleation is decreased lowering the crack growth rate. An optimal $\mathrm{Mg}$ addition inhibits the precipitation of coarse MC car- bide and causes the formation of a number of discrete $\mathrm{M}_{23} \mathrm{C}_{6}$ carbides at grain boundary. The morphology and distribution of carbides at grain boundaries are the major factors in determining the creep behaviour. These structure changes decreased stress concentration at the interfaces/grain boundaries during creep and hence prolong secondary and tertiary creep stages and simultaneously increases ductility at fracture. Generally a large amount of fine and discrete and less number of MC on grain boundary is beneficial for grain boundary strengthening and for inhibiting grain boundary migration. The discrete GB carbides are generally considered beneficial since they inhibit GB sliding and retard the onset of creep cavitation and rupture. Typically over addition of magnesium resulted in an exceptionally high amount of MC carbide at the grain boundary resulting in a sharp decrease in $\mathrm{M}_{23} \mathrm{C}_{6}$ carbides. It has been reported that coarse GB MC carbide could weaken the boundaries and enhance intergranular cracking $[47,48]$. TEM results showed [6] that $\mathrm{Mg}$ addition to alloy GH36 could change grain boundary carbide distribution from continuous plate form to globular shapes and the M23C6 could be distributed in a non-continuous chain form (Figure 9(a), (b)). Fractographic analysis showed that the intergranular cracks changed from wedge type to cavity type to cavity type (Figures 9(c), (d),) in a stress rupture test conducted at $650^{\circ} \mathrm{C}$, which implied $\mathrm{Mg}$ retarded intergranular crack propagation. SEM observation showed ductile fracture characteristics in modified GH 36 alloy in comparison with unmodified GH 36 (Figures 9(e), (f)). All these indicate that $\mathrm{Mg}$ addition strengthens the grain boundaries mainly due to the retardation in intergranular void initiation and the decrease in creep crack growth rate.

Another mechanism of $\mathrm{Mg}$ micro addition in superalloy causing the ductility enhancement, has been put forward by many researchers $[1-2,6,49-51]$, is to purify the grain boundary through binding the detrimental elements like S, P, O etc. However, if the amount of the detrimental species is far below 5 ppm, then this mechanism might not be applicable.

The energy concept is a well-accepted mechanism by many researchers $[2,42,50-52]$. According to this mechanism, $\mathrm{Mg}$ segregates to the grain boundary and carbide/ matrix interfaces leading to the lowering of interfacial energy and consequently increasing the cohesion energy/ rupture energy between the carbide and the matrix or the boundary and the matrix [53,54]. Under this circumstances crack path changes from the carbide/matrix interface to $\gamma / \gamma^{\prime}$ interface, a region having superior ductility [55]. The crack initiation and propagation are eventually retarded and rupture life and elongation are improved.

The beneficial influence of $\mathrm{Mg}$ in changing the GB 

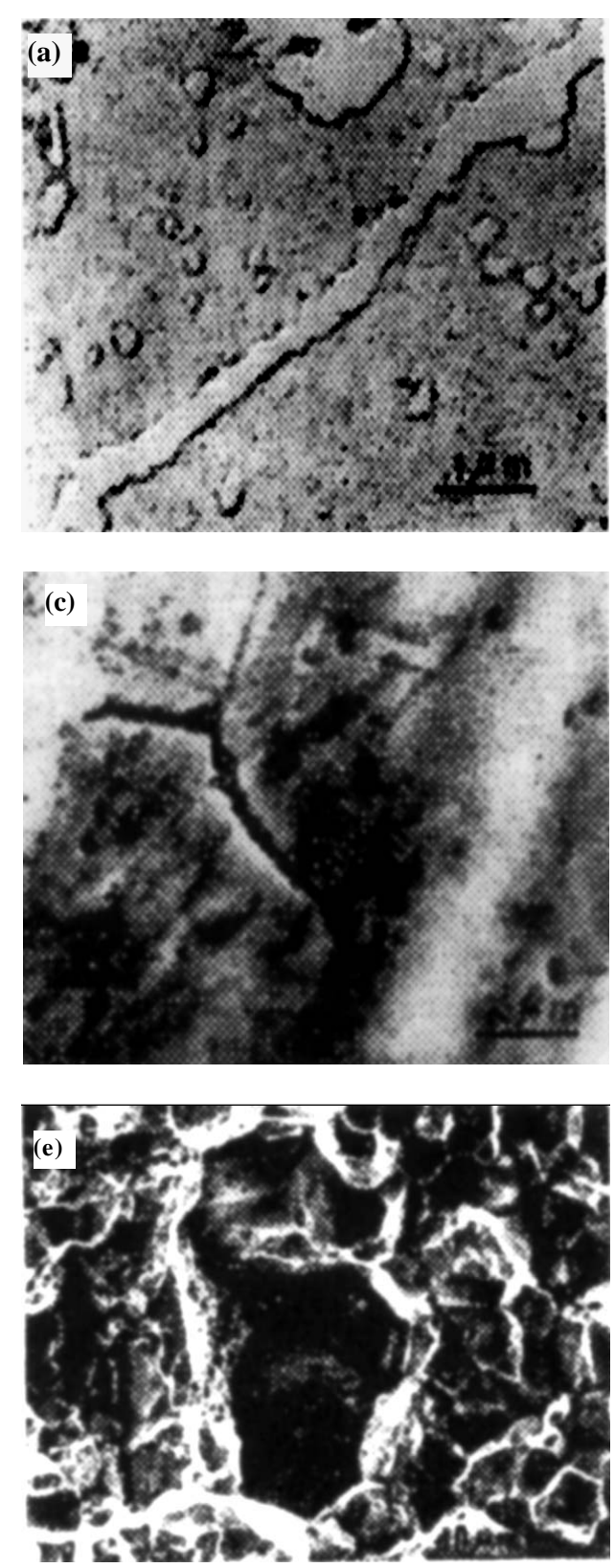
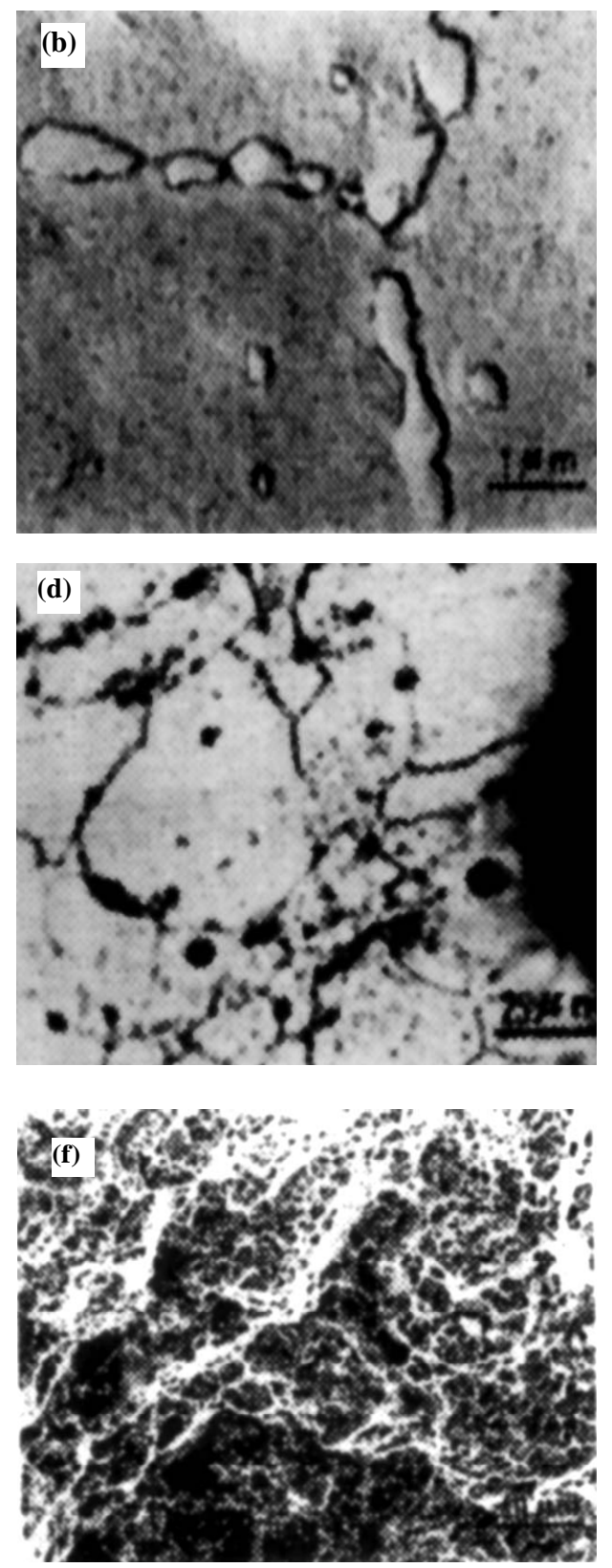

Figure 9. Effect of magnesium on grain boundary carbide morphology (a, b), mode of grain boundary cracks (c, d) and character of intergranular fracture (e, f) of GH 36 [6].

$\delta-\mathrm{Ni}_{3} \mathrm{Nb}$ cellular precipitates is also reported in the literature $[1,4]$. The continuous cellular precipitate/plate like precipitates of $\delta-\mathrm{Ni}_{3} \mathrm{Nb}$ transforms to small amount of phases or discrete globular shapes in the presence of $\mathrm{Mg}$ hence retards intergranular crack growth, which simultaneously increases stress rupture ductility and prolongs failure life. The amount of $\delta-\mathrm{Ni}_{3} \mathrm{Nb}$ depends on grain size, amount of $\mathrm{Mg}$ and heat treatment. However, the addition of $\mathrm{Mg}$ does not reported to have any significant influence on main strengthening phases $\gamma^{\prime}$ and $\gamma^{\prime \prime}[1$, 27]. Micro mechanical phase analysis results showed that the amount of strengthening phases of $\gamma^{\prime}$ and $\gamma^{\prime \prime}$ phase is not affected by $\mathrm{Mg}$ addition or grain size in alloy IN-718 and $718 \mathrm{M}$ as shown in Figure 10 [27]. Mg-free and Mg-containing $718 \mathrm{M}$, both contained approximately $14 \% \gamma^{\prime}+\gamma^{\prime \prime}$ independent of grain size. However, $\delta-\mathrm{Ni}_{3} \mathrm{Nb}$ precipitation at grain boundaries increased with grain refinement and increase in amount of $\mathrm{Mg}$.

It has also been suggested that $\mathrm{Mg}$ with large atomic radius in the grain boundary areas might decrease the vacancy density and the diffusion coefficient of vacancies. The initiation and propagation rate of creep voids 


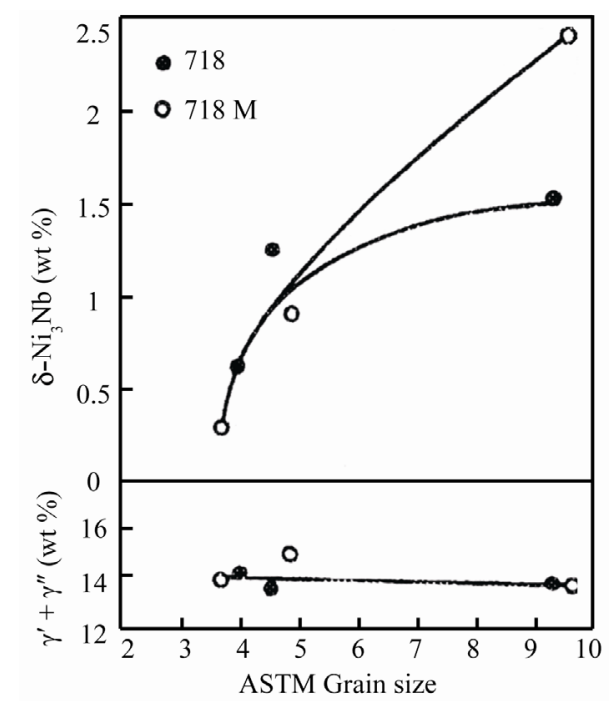

Figure 10. Grain size and Mg effect on the amount of $\gamma^{\prime}+\gamma^{\prime \prime}$ and $\delta$-Ni3Nb [27].

are proportional to the grain boundary diffusion coefficient of vacancies $[56,57]$, therefore, the segregation of $\mathrm{Mg}$ at grain boundary retards the initiation and propagation of creep voids. Concentration of $\mathrm{Mg}$ at grain boundary plays a strengthening role on grain boundaries [58].

The reduction of steady state creep rate at low strain rates pointed out by some researchers is considered to be due to the presence of $\mathrm{Mg}$ in the matrix [4,17]. Lagneberg et al. [59] in their study of the creep behaviour of precipitation strengthening types alloys under various stresses at intermediate temperature reported that at low strain rate condition $\left(\varepsilon<10^{-5} \mathrm{~mm} \cdot \mathrm{mm}^{-1} \cdot \mathrm{h}^{-1}\right)$ the dislocation movement could not be realized by Orwan mechanism or shearing particles but dislocation climbing over $\gamma^{\prime}$ particles. At low strain rate climbing of dislocation on $\gamma^{\prime}$ depends upon vacancy concentration in the matrix. The increase in vacancy activation energy in $\mathrm{Mg}$ containing alloys causes the decrease in vacancy concentration. Therefore, the climbing velocity of dislocation over $\gamma^{\prime}$ a particle reduces and a low steady state creep rate proceeds. At higher strain rate the vacancy concentration arising from the Mg disappears.

\subsection{Formation of Laves Phase}

With an appropriate amount of $\mathrm{Mg}$ in $\mathrm{IN}-718$, the shape of the carbides at the interfaces was found to be smoother than that was without $\mathrm{Mg}$ [54]. The incoherent interfaces like carbide/matrix (or $\gamma^{\prime}$-phase) promoted the formation of small $\mathrm{Ni}_{2} \mathrm{Mg}$, wrapped around the carbides and thus smoothened the carbide shape improving high temperature creep rupture and fracture toughness properties. They have emphasized on the tact that a very small sized Laves phase $(\sim 10 \mathrm{~nm})$ can improve high temp creep properties and this was detected by high resolution electron microscope with $\sim 20 \mathrm{~nm}$ probe size. Zhu et al. [60] also noticed, about the similar wrapping of $\mathrm{Ni}_{2} \mathrm{Mg}$ phase around the carbide, while using TEM. However, the presence of a Laves phase, $\mathrm{Ni}_{2} \mathrm{Mg}$, is considered to be detrimental for mechanical properties.

\subsection{Mg and S Interaction}

The beneficial effect of $\mathrm{Mg}$ on intergranualar fracture has been established by many methods [1]. The Mg influences the growth rate of creep cracks in steady state range. To understand the segregation behaviour of $\mathrm{Mg}$ during creep AES analysis was carried out at the crept specimens at different stages [4]. The tests were interrupted at different stages of the creep test and the specimens were being taken out and broken keeping them in liquid nitrogen to obtain intergranular fracture and hence measured the segregation behaviour of Mg by AES. The $\mathrm{Mg}$ distribution at the grain boundaries was found to be quite inhomogeneous possibly due to the variation of grain boundary structure, or the microstructure near the grain boundary. At the initial stage of creep under the action of applied stress, $\mathrm{Mg}$ and $\mathrm{S}$ solutes redistribute themselves. Hence the Auger peaks of Mg and S at many GBs were eliminated/reduced. The creep cavities then nucleated at the segregation free condition of $\mathrm{Mg}$ so it was assumed that there is no effect of $\mathrm{Mg}$ on the initiation of creep cavities, which contradicted the results mentioning about the active role of $\mathrm{Mg}$ in crack initiation. However, as cavities formed, $\mathrm{Mg}$ and S segregated to the cavity surfaces due to the high surface activity of the elements and stress free condition at cavity surface. It has been reported that the segregation of sulfur at cavity surface with $\mathrm{Mg}$ is less than without Mg containing cavities. According to the cavity growth theory surface tension and surface diffusion coefficient both decrease by $\mathrm{Mg}$ segregation and hence process of cavity growth and link between the cavities are influenced by Mg segregation, which lowers the cavity growth rate [61].

The fracture surface analysis by SEM while conducting hot ductility testing showed ductile appearance at very low level of sulfur [35]. When sulfur increased the fracture surface appeared to be intergranular and sulfur was found on grain boundaries. However, at relatively higher sulfur level the fracture surface showed partially ductile fracture with appropriate $\mathrm{Mg}$ addition and no segregation of $\mathrm{Mg}$ and $\mathrm{S}$ was observed. Furthermore, excessive $\mathrm{Mg}$ addition produced $\mathrm{Mg}$ particles in the alloy matrix and sulfur segregation at grain boundary reduced with ductile fracture but ductility was not improved.

There are some negative views regarding $\mathrm{Mg}-\mathrm{S}$ interaction. The detrimental interaction of these elements have been reported in the work of Liu et al. [7] (2001) 
containing low sulfur content. The fractographic and micrographic analysis by SEM reveal that Mg had little effect on the microstructure of IN-718, i.e. grain size, $\delta$-phase etc. The Auger research revealed no segregation of $\mathrm{Mg}$ at $\mathrm{GB}$. The phase diagram of Ni-Mg shows no solution of $\mathrm{Mg}$ in Ni-matrix and $\mathrm{Mg}$ tends to segregate at the GB of the matrix. However, it is a matter of controversy since IN-718 is a multicomponent system and there is complex interaction among the alloying elements. The sites at grain boundaries, which can absorb solute atoms, are limited. Hence the diffusion velocity of $\mathrm{Mg}$ is lower than that of the other elements and there is no room for $\mathrm{Mg}$ segregation. In this case, $\mathrm{Mg}$ appears either as $\mathrm{MgO}, \mathrm{MgS}$ or $\mathrm{Mg}(\mathrm{O}, \mathrm{S})$. However, $\mathrm{Mg}(\mathrm{O}, \mathrm{S})$ is supposed to increase void nucleation sites, which is detrimental for, mechanical properties. This is the reason put forward by the authors [7] for the opposite effects on mechanical properties of high and low sulfur levels. Moreover, if the sulfur is very low, $\mathrm{Mg}$ forms $\mathrm{Ni}_{2} \mathrm{Mg}$ type of Laves phase. Magnesium had no effect on stress rupture properties of Inconel 718 at $650^{\circ} \mathrm{C}, 686 \mathrm{MPa}$ while the $\mathrm{S} \leq 10 \mathrm{ppm}$ [33]. Liu et al. [7] also reported about the detrimental or no effect of $\mathrm{Mg}(76 \mathrm{ppm}-94$ $\mathrm{ppm}$ ) in their recent studies on IN-718 containing $\mathrm{S}<10$ ppm).

\subsection{Magnesium Segregation}

The segregation behaviour of $\mathrm{Mg}$ to phase interfaces has been established by many using electron microprobe technique, AES and EDS analysis on the TEM thin film and the results showed $\mathrm{Mg}$ segregation at $\mathrm{MC} / \gamma, \gamma^{\prime} / \gamma[62,63]$. The beneficial effects of Mg addition on grain boundaries are related to the grain boundary segregation behaviour and its influence on the grain boundary properties. Due to the segregation of $\mathrm{Mg}$ to the grain boundary, the following changes in the grains may occur [18]:

1) Grain boundary cohesive bond is intensified in terms of the increase and more homogeneous distribution in electron density due to $\mathrm{Mg}$ segregation.

2) Grain boundary dislocation mobility decreases due to $\mathrm{Mg}$ atom segregation to dislocation cores and which may influence the creep rate if the grain boundary creep predominates over the creep in grains.

3) The vacancy formation energy is increased due to $\mathrm{Mg}$ segregation, which results in the decrease in grain boundary vacancy concentration and grain boundary diffusion coefficient.

4) The morphology of grain boundary precipitates may be changed due to the decrease in grain boundary energy, and thus the uniform granular grain boundary precipitates decreased the mobility of grain boundary migration, which results in the retardation of creep void initiation and growth.

By EPM analysis, Mg concentration at the phase interface, interior of MC and the matrix of a Ni base superalloy has been measured $-2.55 \times 10^{-2}, 0.437 \times 10^{-2}$ and $0.956 \times 10^{-2} \%$ respectively. This indicates that $\mathrm{Mg}$ is enriched at the interface of the phases and not the interior of it. TEM analysis of $\gamma^{\prime}$ interface, interior of $\gamma^{\prime}$ and in the matrix were respectively $0.555,0.252$ and 0.256 . Again the segregation of $\mathrm{Mg}$ at the interface is pronounced. Furthermore, AES results of phase interface also showed $\mathrm{Mg}$ segregation at the interface. The $\mathrm{Mg}$ segregation thickness at MC carbide interface is thicker than $\gamma^{\prime}$ phase interface. This is because the lattice mismatch between the carbide and matrix is larger. The structure of MC carbide interface is incoherent and has a large deformed area. It creates a favourable thermodynamic condition for the $\mathrm{Mg}$ atom to segregate to $\mathrm{MC}$ phase interface. If $\mathrm{Mg}$ atom enters $\mathrm{MC}$ phase it increases Gibbs free energy, as a result it segregates at the interfaces instead of the interior of the carbide. On the other hand, $\gamma^{\prime}$ phase interface is semi-coherent and the structure of the interface consists of dislocation arrays and impurities and the degree of distortion is also less-hence the segregation of $\mathrm{Mg}$ is easier in this case.

Basically, the driving force for grain boundary segregation of an element is the elastic distortion energy, which is proportional to the square of the mismatch between the atomic radius and the unoccupied hole radius. Hence, $\mathrm{Mg}$ should have a strong tendency to segregate to the GB due to its larger atomic radius compared with $\mathrm{Nb}$ and Mo. In addition, from the segregation theory, the solubility of an element in a matrix is an indication of the ability of an element to segregate, i.e., lower the solubility the stronger the tendency to segregate. Since the solubility of $\mathrm{Mg}$ is much less than $\mathrm{Nb}$, Mo and $\mathrm{W}$, $\mathrm{Mg}$ segregates to the grain boundary. As the mismatch of $\mathrm{Mg}$ and $\mathrm{Nb}$ both are positive, a repulsive interaction between $\mathrm{Mg}$ and $\mathrm{Nb}$ segregation can be expected. $\mathrm{Mg}$ causes an additional lattice distortion and this distortion assumed to have promoted " $\mathrm{B}$ " and "C" segregation at $\mathrm{GB}$. It is therefore, assumed that $\mathrm{Mg}$ segregation causes $\mathrm{Nb}$ segregation to decrease and the segregation of ' $\mathrm{B}$ ' and " $\mathrm{C}$ " to increase. Additional potential energy generated from the lattice distortion caused by $\mathrm{Mg}$ atoms may accelerate the segregation of " $\mathrm{B}$ " at the GB [64]. Hence $\mathrm{Mg}$ helps eliminate the thick lamellae [65] or brittle strips of $\mathrm{NbC}$ and $\delta-\mathrm{Ni}_{3} \mathrm{Nb}$ along the GB $[52,65]$. An example of globular type $\mathrm{Ni}_{3} \mathrm{Nb}$ along grain boundary of $\mathrm{Mg}$ (0.0094) containing GH 169 alloy is presented as opposed to cellular precipitates at grain boundary of alloy with negligible amount of $\mathrm{Mg}(0.0001)$ (Figure 11) [1]. 


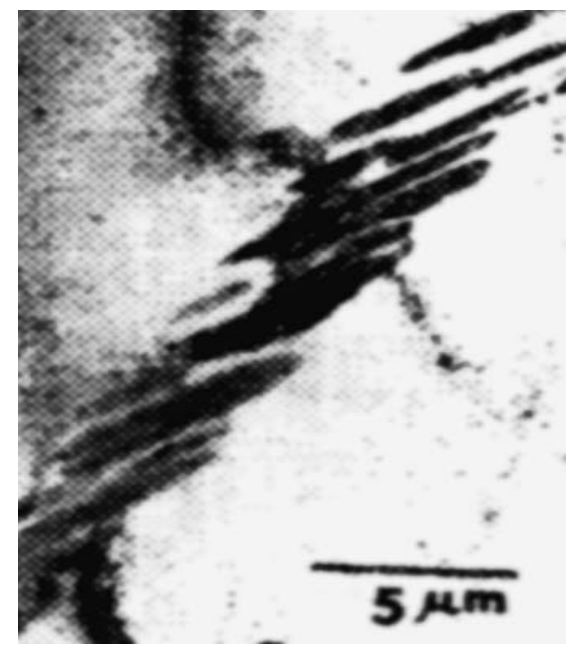

(a)

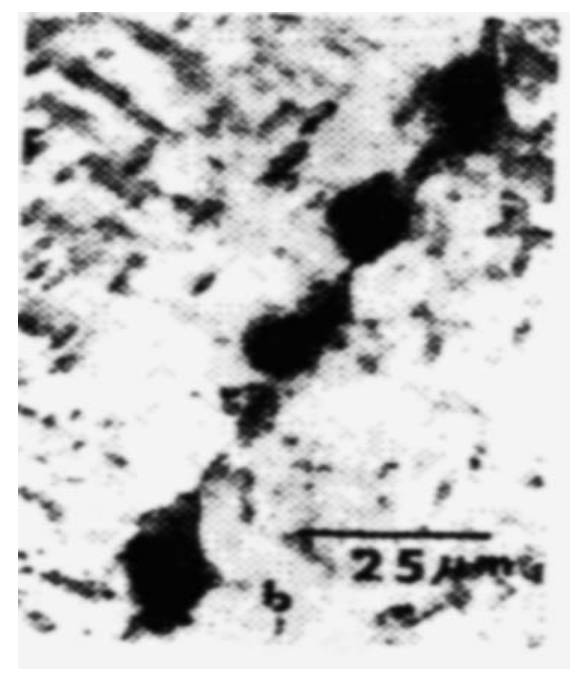

(b)

Figure 11. The influence of Mg on grain boundary $\delta$-Ni3Nb precipitation in GH 169 (a) without $\mathrm{Mg}(0.0001)$ (b) with Mg (0.0094) [1].

\section{4. $\mathrm{Mg}$ in Carbides and Matrix}

The literatures $[17,52,66]$ indicate that $\mathrm{Mg}$ not only segregates along GB but also into the carbides of GB and $\gamma^{\prime}$ phase either along grain boundary or in the grains. The $\mathrm{Mg}$ dissolved in the $\gamma^{\prime}$ phase and carbides lead to the composition change, i.e., increases the contents of $\mathrm{W}$, $\mathrm{Mo}$ and $\mathrm{Ti}$ in the phases and therefore changes their lattice constants and increases the elastic energy, which is proportional to the increase in $\mathrm{M}_{23} \mathrm{C}_{6}$ thickness by causing a large distortion due to the large atomic radius of $\mathrm{Mg}$. Thus as the thickness of $\mathrm{M}_{23} \mathrm{C}_{6}$ reaches a critical value, the coherent interface becomes semi or incoherent, resulting in decrease in long range stress field and a decrease in total energy [66]. It is noteworthy that a pre- cipitate phase always tends to minimize its surface energy. Hence the $\mathrm{M}_{23} \mathrm{C}_{6}$ with incoherent interface gradually becomes granular-which is beneficial for mechanical properties. However, over addition of $\mathrm{Mg}$ caused $\mathrm{M}_{23} \mathrm{C}_{6}$ lamellae to precipitate due to the increase of supersaturation of carbon at the GB [1].

\subsection{Behaviour of $\mathrm{Mg}$ in Cast Superalloys}

Mg improves the solidification structure of cast superalloys [5]. It segregates to phase boundaries and refines the interdendritic MC carbides and $\gamma^{\prime}$ eutectic-decreasing quantity of $\gamma^{\prime}$ eutectic. The addition of $\mathrm{Mg}$ influences the grain size and decrease the secondary arm spacing. As a result, the interdendritic precipitates like Laves phase and $\mathrm{MC}$ eutectic are reduced. A decrease in $\mathrm{Nb}$ segregation was also reported by using electron microprobe analysis and this was considered good since MC eutectic and Laves phase were the results of $\mathrm{Nb}$ segregation. The morphology of $\mathrm{MC}$ also changed to spheroidal due to the addition of Mg. Hence an optimum amount of Mg decreases $\mathrm{Nb}$ segregation and decreases initial cast segregation. which shortens homogenization cycle? However, the amount of $\delta-\mathrm{Ni}_{3} \mathrm{Nb}$ plate around laves island increased. This occurs because the $\mathrm{Nb}$ available for Laves phase formation is too low but the $\mathrm{Nb}$ content for $\delta$ plate formation is high. Although both the phases are generally considered to be detrimental, however, the elimination of $\delta-\mathrm{Ni}_{3} \mathrm{Nb}$ by homogenization is much easier than the elimination of laves islands.

\section{Level of Mg in Superalloys}

The content of Mg from 30 - 70 ppm showed beneficial effect in improving plasticity, high temperature tensile ductility, stress rupture life, notched cyclic stress $\mathrm{ru} \sim 1$ ture life and creep fatigue interaction ability [3]. The effect of Mg from 1 - $350 \mathrm{ppm}$ on mechanical properties was studied and $30-200 \mathrm{ppm}$ was reported to have beneficial effect on stress rupture ductility improvement -no data was presented in the lower range (up to 100 ppm) [28]. An enhanced stress rupture ductility effect was reported by addition of $30 \mathrm{ppm} \mathrm{Mg} \mathrm{[29].} \mathrm{A} \mathrm{remark-}$ able stress rupture ductility and life improvement was noticed with a small addition of $\mathrm{Mg}$ (13 - $19 \mathrm{ppm})$ [30]. The mechanical properties like tensile and stress rupture ductilities, smooth and notch stress-rupture lives, fatiguecreep interaction properties were reported to have increased by $59 \mathrm{ppm}$ addition of $\mathrm{Mg}$ (S-40 ppm) [27]. Stress rupture and creep properties improve by the addition of $94 \mathrm{ppm} \mathrm{Mg}$ in a vacuum melted IN-718 (S-50 $\mathrm{ppm}$ ) [1]. The effect of $\mathrm{Mg}$ on cast alloys was reported to be beneficial in the optimum range of $40-80 \mathrm{ppm} \mathrm{Mg}$ addition [5]. By the addition of $20 \mathrm{ppm} \mathrm{Mg}$ impact 
toughness was reported to have improved and influenced favourably the distribution of interdendritic Laves and $\mathrm{MC}$ particles. The materials contained $\mathrm{Mg}$ in the range of $0-110 \mathrm{ppm}$. In a study with $50 \mathrm{ppm} \mathrm{Mg}$ level it was concluded that Mg had no effect on LCF but creep properties enhanced (S-40 ppm) [26]. High temperature creep properties were increased by the addition of $59 \mathrm{ppm} \mathrm{Mg}$ [32]. An improved influence of $\mathrm{Mg}$ on stress rupture, high tem- perature tensile ductility, fatigue creep interaction properties were reported with $59 \mathrm{ppm} \mathrm{Mg}$ [5].

No effect or detrimental effect of $\mathrm{Mg}$ has been reported in some literature [7]. The Mg did not show any influence on tensile strengths and ductilities and stress rupture life reported to have decreased when sulfur is less than $10 \mathrm{ppm}$. $\mathrm{Mg}$ added was 0,76 and $94 \mathrm{ppm}$ (S-10 ppm).

\section{Thrust Areas for Further Work}

From the literature review it is obvious that the studies have been made on the high temperature tensile, creep, fatigue and impact toughness properties of $\mathrm{Mg}$ containing superalloys, including IN-718 alloy in question. However, the studies on weldability of the material are scarce if non-existent. In late 1960s the weldability measurement by conducting gleeble hot ductility test was performed by Morrison et al. [34], and the beneficial role of $\mathrm{Mg}$ on weldability was reported. However, there was no mention about the production route of the material. Since there is propensity for the material to pick up $\mathrm{Mg}$ during melting practice-from the furnace lining, crucible or the slag-the amount of optimum Mg reported by their study, which was considered to have beneficial influence on the weldability of the Mg containing IN-718 was debatable. Moreover, Laves phase formation present in the dendritic structure poses difficulty during welding of IN-718 and as it has been observed in the literature that an optimum amount of Mg can modify the Laves phase and improve mechanical properties it is again worthwhile to study the role of $\mathrm{Mg}$ in influencing the weldability of IN-718. Furthermore, Mg being a surface-active element has the tendency to segregate at the interfaces and grain boundaries and hence it might have great impact in affecting intergranular liquation cracking in HAZ region of the weldments. In addition it is imperative to study the interactive effect of $\mathrm{Mg}$ with the detrimental elements like S, P, and especially B in assessing the weldability behaviour of superalloys produced by using the vacuum technological routes (VIM, VAR and VADER).

\section{Conclusions}

1) Microalloying of $\mathrm{Mg}$ shows beneficial effect of decreased low cycle fatigue crack growth rate by a factor of
3-7.

2) $\mathrm{Mg}$ prolongs secondary and tertiary creep at low strain rate $\left(\varepsilon<10^{-5} \mathrm{~mm} \cdot \mathrm{mm}^{-1} \cdot \mathrm{s}^{-1}\right)$ of steady state and also prolongs rupture creep strength and elongation.

3) $\mathrm{Mg}$ refines and spheroidizes $\mathrm{MC}$ carbide at $\mathrm{GB}$, thus improving the stress distribution state at $\mathrm{GB}$, which in turn has decreases the possibility of wedge crack at the GB. This enhances the creep properties.

4) Beneficial and detrimental effects of $\mathrm{Mg}$ addition on rupture life and elongation, depend upon the operating stress and temperature.

5) $\mathrm{Mg}$ can improve tensile strength and ductility at high as well as low temperature.

6) $\mathrm{Mg}$ has been found to improve impact toughness, which is possibly due to the decrease in interdendritic Laves eutectic and the refinement of interdendritic segregation of $\mathrm{Nb}$ and $\mathrm{Ti}$, which allowed shorter homogenisation cycle.

7) The effect of $\mathrm{Mg}$ on hot ductility behaviour is reported to be controversial.

8) $\mathrm{Ni}_{2} \mathrm{Mg}$ (Laves phase) wrapping around $\mathrm{MC}$ has been found to smoothen the carbide shape, thus improving high temperature creep and fracture properties.

9) $\mathrm{Mg}$ scavenges sulfur giving ductile fracture with no magnesium and sulfur segregation on GB.

10) $\mathrm{Mg}$ helps eliminate thick lamellae or brittle strips of $\mathrm{NbC}$ and $\delta-\mathrm{Ni}_{3} \mathrm{Nb}$ along the GB.

11) Segregation of $\mathrm{Mg}$ has been shown to occur into $\mathrm{M}_{23} \mathrm{C}_{6}$ and $\gamma^{\prime}$ apart from along grain boundary and other surfaces. Thus the $\mathrm{Mg}$ containing $\mathrm{M}_{23} \mathrm{C}_{6}$ phase with incoherent interface becomes granular, which is beneficial for mechanical properties.

12) In cast superalloys the segregation of $\mathrm{Mg}$ to phase boundaries improves the solidification structure and thus refining $\mathrm{MC}$ and $\gamma^{\prime}$ eutectic. $\mathrm{Mg}$ also decreases secondary arm spacing and thus reducing interdendritic precipitates like MC and Laves eutectic.

13) The study of the effect of Mg in influencing HAZ liquation cracking and weldability of superalloys has been proposed.

\section{REFERENCES}

[1] G. Chen, D. Wang and Z. Xu, "Proceedings Superalloys 1984,” In: M. Gell, C. S. Kortovich, R. H. Bricknell, W. B. Kent and J. F. Radavich, Eds., The Metallurgical Society, AIME, Warrendale, PA 15086, 1984, pp. 611-620.

[2] Z. Zhong, P. Ma, J. Zhuang, Y. Yuan and N. Jim, Proceedings Superalloy 1992, TMS, Warrendale, PA, 1992, pp. 629-635.

[3] J. Dong, W. Xie, Z. Xu, X. Xie and S. Zhang, Acta Metallurgica Sinica, Vol, 6. No. 6, 1993, pp. 405-409.

[4] P. Ma, Y. Yuan and Z. Zhong, Acta Metallurgica Sinica,Vol. 3, No. 3, 1990, pp. 208-212. 
[5] G. Chen, Q. Zhu, D. Wang, X. Xi and J. F. Radavich, Proceedings Superalloy 718, E. A. Loria, Ed., TMS, Warrendale, PA, 1989, pp. 545-551.

[6] X . Xie, J. Liang and H. Jiang, Elsevier Applied Science, 1987, pp. 719-723.

[7] X. Liu, J. Dong, X. Xie and K. Chang, "The Appearance of Magnesium and Its Effect on the Mechanical Properties of Inconel 718 with Low Sulfur Content," Materials Science and Engineering A, Vol. 303, 2001, pp. 262-266. doi:10.1016/S0921-5093(00)01789-5

[8] D. A. Ford, Metals Technology, Vol. 11, No. 10, 1984, pp. 438-445.

[9] Z. M. Kalinina, et al., Production of Electric Steel' (Proizvodstvo Clektrostali), 1972, pp. 94-100.

[10] Z. M. Kalinina, et al., Production of Electric Steel' (Proizvodstvo Clektrostali), 1972, pp. 89-94.

[11] Z. M. Kalinina, et al., "Effect of Microalloying with Magnesium on Structure and Properties of Nickel Base Alloys," Proceedings Production of Steels and Alloys in Vacuum, Electroslag and Electron Beam Furnaces (in Russian), Part 2, Chermetinformatsiya, 1971, pp. 30-32.

[12] O. V. Rutes, G. S. Chernyak and S. B. Maslenkov, "Effect of $\mathrm{Mg}, \mathrm{Ca}$ and $\mathrm{Ba}$ on structure and properties of heat-resistant alloys hardened with $\mathrm{Ni}_{3} \mathrm{Al}$," Special Steels and Alloys (in Russian), Metallurgiya, No. 2, 1973, pp. 41-47.

[13] G. S. Chyernyak, O. V. Rutes and S. B. Maslenkov, "Effect of Magnesium and Calcium on Structure and Properties of Heat-Resistant Alloys," Special Steels and alloys (in Russian), Metallurgiya, No. 1, 1972, pp. 89-97.

[14] Z. M. Kalinina, et al., Metall (Metalli) SSSR, No. 4, 1973, pp. 193-196.

[15] V. V. Topilin and V. K. Versina, Quality Steels and Alloys, Moscow, 1976, pp. 108-113.

[16] V. V. Topilin and V. K. Versina, Metalloved. Term Obrab Met., Vol. 11, 1977, pp. 10-13.

[17] P. Ma, Y. Yuan and Z. Zhong, "Creep Behavior of Magnesium Microalloyed Wrought Superalloys," Proceedings Superalloys 1988, The Metallurgical Society/AIME, 1988, pp. 625-633.

[18] G. Chen and H. Ge, Journal of University of Science \& Technology, Beijing, Vol. 2, No. 2, 1995, pp. 84-91.

[19] Y. Li, C. Sun, J. Liu and G. Chen, High Temperature Technology, Vol. 5, No. 4, November 1997, pp. 201-204.

[20] Guo E. and F. Xu, Acta Metallurgica Sinica, October 1988, pp. 957-962.

[21] D. Ke, Acta Metallurgica Sinica, Vol. 19, No. 5, October 1983, pp. a377-a384.

[22] H. Y. Bor, C. Y. Ma and C. G. Chao, "The Influence of $\mathrm{Mg}$ on Creep Properties and Fracture Behaviors of Mar-M247 Superalloy under 1255 K/200 MPa", Metallurgical and Materials Transactions A, Vol. 31A, May 2000, pp. 1365-1373.

[23] H. Y. Bor, C. G. Chao and C. Y. Ma, "The Influence of Magnesium on Carbide Characteristics and Creep Be- havior of the Mar-M247 Superalloy," Scripta Materialia, Vol. 38, No. 2, 1998, pp. 329-335.

[24] H. Y. Bor, C. G. Chao and C. Y. Ma, "The Effects of Mg Micro Addition on the Mechanical Behavior and Fracture Mechanism of MAR-M247 Superalloy at Elevated Temperatures," Metallurgical and Materials Transactions A, Vol. 30A, No. 3, 1999, pp.551-561.

[25] G. L. Chen, T. H. Zhang and W. Y. Yang, High Temperature Technology, Vol. 6, No. 3, 1988, pp. 149-152.

[26] G. Chen, X. Xie, Z. Xu, J. Zhang, Chinese Journal of Metal Science and Technology, Vol. 7, No. 6, 1991, pp. 435-441.

[27] X. Xie, Z. Xu, B. Qu, G. Chen and J. F. Radavich, Superalloys 1988, S. Reichman, D. N. Duhl, G. Maurer, S. Antolovich and C. Lund, Eds., AIME, Warrendale, PA, ,The Metallurgical Society/AIME, $420 C^{\prime}$ wealth Dr., Warrendale, PA, 1988, pp. 635-642.

[28] W. H. Couts Jr., et al, "Effect of Mg as an Alloying Element in IN-718," Report AEML-TR-7s-76, 1971.

[29] D. R. Muzyka and C. R. Whitney, "Process for Making Ni-Base Precipitation Hardenable Alloys," U.S. Patent 3,575,734, 20 April 1971.

[30] J. M. Moyer, "Extra Low Carbon Alloy 718," Proceedings Superalloys 1984, The metallurgical Society/AIME, 420 C'wealth Dr. Warrendale, PA 15086, pp. 223-254.

[31] Z. Xu, X. Xie, B. Qu, G. Chen and J. F. Radavich, Science and Technology Beijing, Vol. 2, No. 6, 1989, pp. 560-567.

[32] Z. Xu, B. Xu, X. Xie, S. Zhou and X. F. Cheng, Journal of Beijing University of Iron and Steel Technology, Vol. 9, No. 4, 1987, pp. 38-44.

[33] X. S. Xie, J. X. Dong and M. C. Zhang, "Research and Development of Inconel 718 Type Superalloy," Materials Science Forum, Vol. 539-543, March 2007, pp. 262-269.

[34] T. J. Morrison, et al, Proceedings Symposium of Welding Research Council, Department of Mechanical Engineering, University of Manitoba, Winnipeg, Canada R3T 2N2, 1969, pp. 47-67.

[35] V. V. Topilin and Tsvetkova, Metalloved. Ternl. Obrab. Met., Vol. 2, February 1980, pp. 62-64.

[36] K. Liu, et al., Proceedings 7th Symposium on Environmental Degradation, Breckenridge, Co, USA, 1995, pp. 509-517.

[37] S. Yamaguchi, H. Kobayashi, T. Matsumiya and S. Hayami, Metals Technology, May 1979, pp. 170-175.

[38] E. O. Ezugwu. J. Bonney and Y. Yamane, "An Overview of the Machinability of Aeroengine Alloys," Journal of Materials Processing Technology, Vol. 134, 2003, pp. 233-253. doi:10.1016/S0924-0136(02)01042-7

[39] T. Baumgartner, K. Bothe, S. Hurta, W. M. Laanemae and V. Gerold, "Thermomechanical Fatigue of Nimonic 80A," Advanced Materials and Processes-Proceedings of the First European Conference. EUROMAT '89. Vol. 1, Aachen, FRG, 22-24 November 1989. pp. 535-540.

[40] R. Sunulahpasic and M. Oruc, Metallurgica, Vol. 50, No. 
3, 2011, pp. 155-158.

[41] J. Fu, H. Wang and E. P. Chen, Proceedings 7th ICVM, Tokyo, Japan, 1982, p.1226.

[42] J. Fu and L. Gao, J. Vacuum Science and Technology, Vol. 5A, No. 4, Part 4, 1987, p. 2687.

[43] J. Fu and L. Song, Proceedings 10th International Conference on Vacuum, Metallurgical Industry Press-Peoples Republic of China, Beijing, China, 1991, pp. 160-168.

[44] W. Yeniscavich and C. W. Fox, Proceedings Symposium of Welding Research Council, Department of Mechanical Engineering, University of Manitoba, Winnipeg, Canada R3T 2N2, 1969, pp. 24-35.

[45] F. Wang, Metal Physics, Mechanical Industry Press, Beijing, 1981, p. 47.

[46] D. Ke and Z. Zhong, Acta Metallurgica Sinica, 1983, p. A377.

[47] P. S. Kotval, J. D. Venables and R. W. Calder, Metallurgical Transactions A, Vol. 3, 1972, pp. 453-458.

[48] G. R. Leverant and M. Gell, Transactions TMS-AIME, Vol. 245, 1969, pp. 1167-1173.

[49] G. S. Chyernyak, A. V. Smirnova and S. B. Maslenkov, Metall.(Metalli.) SSSR, No. 1, 1973, pp. 98-104.

[50] D. Ke, Masters Thesis, CISRI, Beijing, China, 1981.

[51] V. V. Topilin, Steel USSR, 1978, pp. 643-646.

[52] D. Ke and Z. Zhong, Acta Metallurgica Sinica, Vol. 19, 1983, p. A377.

[53] P. Ma J. Zhuang, J. Yang and L. Gao, Acta Metallurgica Sinica, Vol. 23, 1987, p. A195.

[54] D. Ke and Z. Zhong, CISRI Technical Bulletin, Vol. 73, 1983, p. 3.

[55] J. Zhu, Z. Y. Cheng and H. Q. Ye, "The Distribution and
Morphology of Trace $\mathrm{Mg}$ at a Grain Boundary in a Ni-Base Superalloy," Scripta Metallurgica, Vol. 23, 1989, pp. 1537-1542. doi:10.1016/0036-9748(89)90124-5

[56] K. L. Gasko, G. M. Janowski and B. J. Pletka, "The Influence of $\gamma-\gamma^{\prime}$ Eutectic on the Mechanical Properties of Conventionally Cast MAR-M247," Materials Science and Engineering, Vol. 104A, October 1988, pp. 1-8.

[57] A. S. Argon, I-W. Chen and C.-W. Lan, Proceedings Creep-Fatigue Environmental Interaction, AIME, New York, 1980, pp. 46.

[58] R. J. Raj, Engineering Materials Technology, Vol. 98, 1976, p. 132. doi:10.1115/1.3443355

[59] R. Lagneberg and B. Bergman, "The Stress/Creep Rate Behaviour of Precipitation-Hardened Alloys," Metals Science, Vol. 10, No. 1, 1976, pp. 20-28. doi: $10.1179 / 030634576790431462$

[60] J. Zhu, P. Ma, S. Zhang and L. Gao, Proceedings XIth International Conference on Electron Microscopy, Kyoto, Japan, 1986, pp. 851-852.

[61] T-J. Chuang and J. R. Rice, "The Shape of Intergranular Creep Cracks Growing by Surface Diffusion," Acta Metallurgica, Vol. 21, 1973, pp. 1625-1628. . doi:10.1016/0001-6160(73)90105-3

[62] Q. Zhu, D. Wang, H. Ge and G. Chen, Acta Metallurgica Sinica, June 1989, pp. A185-A189.

[63] Q. Zhu, D. Wang, H. Ge and G. Chen, Acta Metallurgica Sinica, Vol. 2A, No. 6, 1989, pp. 408-411.

[64] V. V. Topilin, Stahl, Vol. 11, 1978, p. 1074.

[65] Y. Li, B. Xu, High Temperature Technology, Vol. 6, No. 4, November 1988, pp. 203-209.

[66] R. Ming, "Physical Basis of Crystal Growth", Shanghai Science \& Technology Press, Shanghai, 1982, p. 364. 